\title{
Deteksi perakaran kelor (Moringa oleifera Lamk) dengan metode geolistrik resistivitas
}

\author{
Root detection of moringa (Moringa oleifera Lamk) with the geoelectric resistivity method \\ Catur Wasonowati ${ }^{1 *}$, Endang Sulistyaningsih ${ }^{2}$, Didik Indradewa ${ }^{2}$, Budiastuti Kurniasih ${ }^{2}$ \\ ${ }^{1}$ Program studi Agroekoteknologi, Fakultas Pertanian, Universitas Trunojoyo Madura \\ ${ }^{2}$ Departemen Budidaya Pertanian, Fakultas Pertanian, Universitas Gadjah Mada \\ *Email korespondensi: caturwasonowati@gmail.com
}

Diterima: 13 Juli 2021 / Disetujui: 10 September 2021

\begin{abstract}
Moringa oleifera Lamk is a multipurpose plant and contains high enough nutrients so that it can be used as an alternative food ingredient. Plants with good roots are able to grow, develop and produce optimally. Destructive sampling of moringa roots takes a long time and was less effective and requires labor. One of the non-destructive methods was to use the geoelectric resistivity method to detect plant roots and study the soil-root relationship. The research was conducted in Bluto and Guluk-guluk Districts, Sumenep Regency. The study was conducted in May 2017. The study was to determine the distribution pattern of the roots of the Moringa plant. In this study, identification of the distribution of primary, secondary and tertiary roots in Moringa plants was carried out using the geoelectric method. The distribution of Moringa roots in Bluto and Guluk-guluk varies, consisting of tertiary, secondary and primary roots, it can be seen from the horizontal and vertical resistivity results. The resistivity value of the Moringa planting location in Bluto was higher than that in Guluk-guluk.
\end{abstract}

Key words: moringa, geoelectricity, resistivity, root.

\section{ABSTRAK}

Tanaman kelor (Moringa oleifera Lamk) sebagai tanaman multiguna dan mengandung zat nutrisi yang cukup tinggi sehingga dapat dijadikan bahan pangan alternatif. Tanaman dengan perakaran yang baik mampu tumbuh, berkembang dan berproduksi secara maksimal. Pengambilan sampel akar kelor dengan cara destruktif membutuhkan waktu yang lama dan kurang efektif serta membutuhkan tenaga kerja. Salah satu metode non destruktif adalah menggunakan metode geolistrik resistivitas (tahanan jenis) untuk mendeteksi akar tanaman dan mempelajari hubungan tanah dan akar. Penelitian dilaksanakan di Kecamatan Bluto dan Guluk-guluk, Kabupaten Sumenep. Penelitian dilaksanakan pada bulan Mei 2017. Penelitian untuk mengetahui bagaimana pola sebaran akar tanaman kelor. Pada penelitian ini dilakukan identifikasi sebaran akar primer, sekunder, dan tersier pada tanaman kelor dengan metode geolistrik. Sebaran akar kelor di Bluto dan Gulukguluk bervariasi terdiri dari akar tersier, sekunder dan primer dapat dilihat hasil resistivitas secara horisontal dan vertikal. Nilai resistivitasnya lokasi tanam kelor di Bluto lebih tinggi dibandingkan dengan di Guluk-guluk.

Kata kunci: akar, kelor, geolistrik, resistivitas

\section{PENDAHULUAN}

Tanaman kelor (Moringa oleifera Lamk) banyak tumbuh, mudah dibudidayakan dan telah terbukti dimanfaatkan dengan baik di Indonesia, karena tanaman ini sangat bergizi dan memiliki berbagai manfaat potensial karena mengandung zat nutrisi yang cukup tinggi seperti multi vitamin, protein yang tersusun dari asam amino esensial dan sumber antioksidan alami seperti asam askorbat, flavonoid, phenolid dan karotenoid dibandingkan dengan kandungan daun tanaman lain (Makkar dan Becker, 1996). Budidaya tanaman kelor agar berhasil, sangat dipengaruhi dan ditentukan oleh beberapa faktor yaitu seperti bahan tanaman, iklim, pemeliharaan tanaman, organisme pengganggu tanaman dan penanganan panen dan pascapanen (Risza, 1994). Kondisi akar sebagai organ tanaman untuk menyerap hara dari dalam tanah yang baik akan memberikan pertumbuhan tanaman yang baik. Perkembangan akar tanaman menyebar ke arah vertikal dan lateral mengikuti perkembangan umur tanaman (Martoyo, 2001).

Perakaran sebagai organ utama tanaman untuk menyerap air dan hara dari dalam tanah menentukan pertumbuhan dan perkembangan tanaman. Tanaman dengan perakaran yang baik mampu tumbuh, berkembang dan berproduksi secara maksimal. Pengambilan sampel akar kelor dengan cara destruktif membutuhkan waktu yang lama dan kurang efektif serta membutuhkan tenaga kerja. Salah satu metode non destruktif adalah menggunakan metode geolistrik resistivitas (tahanan jenis) untuk medeteksi akar tanaman dan mempelajari hubungan tanah dan akar. Menurut Al Hagrey (2007), metode resistivitas sebagai metode pengukuran non destruktif pada akar tanaman dan 
pepohonan. Oleh karena itu, diperlukan penelitian untuk mengetahui bagaimana pola sebaran akar tanaman kelor dengan identifikasi batas sebaran akar primer, sekunder, dan tersier pada tanaman kelor dengan metode geolistrik resistivitas.

\section{BAHAN DAN METODE}

Penelitian dilaksanakan di Kecamatan Bluto dan Guluk-guluk Kabupaten Sumenep. Penelitian dilaksanakan pada bulan Mei 2017.

Bahan yang digunakan dalam penelitian ini adalah tanaman kelor yang berumur lebih dari 5 tahun yang ditanam pada lahan tegalan. Peralatan yang digunakan meliputi : meteran, seperangkat alat geolistrik dan alat tulis.

Metode geolistrik cukup sederhana dan murah, metode geolistrik merupakan metode yang menggunakan prinsip aliran arus listrik dalam menyelidiki struktur bawah permukaan bumi. Metode pengukuran data geolistrik resistivitas dilakukan dalam dua lintasan menbentuk garis lurus pada barisan tanaman kelor. Pengamatan dan pengukuran akar pada tanaman kelor dilakukan dengan langkah-langkah sebagai berikut : 1) menanam elektroda sedalam 5-10 cm dimana ujung elektroda dihubungkan dengan rangkaian alat geolistrik, jarak antara elektroda tergantung dari konfigurasi yang digunakan; 2) menyusun rangkaian elektroda untuk konfigurasi wenner dan mengaktifkan UPS yang berfungsi sebagai power supply lalu mengalirkan arus listrik ke medium di bawah permukaan bumi; 3) set multimeter pada arus dan voltase pada gelombang AC; 4) mencatat arus listrik yang mengalir melalui kedua elektroda arus (I) pada beda potensial $(\Delta \mathrm{V})$ yang dihasilkan melalui kedua multimeter; 5) melakukan pengukuran pada langkah (1) dan (2) dengan variasi panjang bentang elektroda (a) mulai 0,25-2m; 6) menghitung p dan $\mathrm{K}$ dalam program Microsoft Excel dan selanjutnya diconvert dalam file.dat; 7) memasukkan data-data resistivitas (file.dat) ke dalam software RES2DINV (Arifin dan Putra, 2015).
Hasil pengukuran dengan menggunakan metode geolistrik resistivitas pada kedua lokasi yaitu Bluto dan Guluk-guluk dengan 2 lintasan yaitu :

\section{a. Lokasi Bluto lintasan 1 dan 2}

Hasil pengukuran pada lokasi Bluto lintasan pertama, bila ditinjau dari sebaran resistivitas secara horisontal yaitu berjarak 0,25 m sampai dengan 7,75 $\mathrm{m}$ terlihat adanya resistivitas rendah sekitar $157 \Omega \mathrm{m}$ (biru tua hingga biru muda) dari permukaan tanah sampai kedalaman $0,338 \mathrm{~m}$ dari permukaan tanah pada lintasan $2-3 \mathrm{~m}$ dan $5,5 \mathrm{~m}$. Nilai resistivitas sedang 501- 1601 (warna hijau muda hingga hijau tua) terdapat pada kedalaman 0,194 m pada lintasan 4,5-7,5m, sedangkan nilai resistivitas tinggi berkisar 5116 (warna kuning) pada kedalaman 0,0625m pada lintasan 5,5$6,5 \mathrm{~m}$. Secara vertikal nilai resistivitas bervariasi dari rendah, sedang, dan tinggi pada kedalaman 0,0625-1,00 m Gambar 1. Pada lokasi Bluto lintasan 1 secara horisontal lapisan yang paling atas didominasi oleh perakaran sekunder dengan sedikit akar tersier. Sedangkan secara vertikal bervariasi antara perakaran primer, sekunder dan tersier.

Pengukuran pada lokasi Bluto lintasan kedua, bila ditinjau dari sebaran resistivitas secara horisontal yaitu berjarak 0,25 m sampai dengan 7,75 m terlihat adanya nilai resistivitas rendah sekitar 203-375 $\Omega \mathrm{m}$ (biru tua hingga biru muda) dari permukaan tanah sampai kedalaman $0,497 \mathrm{~m}$ dari permukaan tanah pada $0,5-2,0 \mathrm{~m}, 2,5-4,75 \mathrm{~m}, 6-7,5 \mathrm{~m}$. Nilai resistivitas sedang 1278-2358 (warna hijau muda hingga hijau tua) terdapat pada kedalaman 0,672 m pada lintasan 5-6,25m, sedangkan nilai resistivitas tinggi berkisar 4352 (warna kuning) dari permukaan tanah sampai kedalaman 0,194 m pada lintasan 5-6 m. Secara vertikal nilai resistivitas bervariasi antara kecil, sedang dan tinggi pada kedalaman 0,0625-1,00m (Gambar 2). Pada lokasi Bluto lintasan 2 secara horisontal lapisan yang paling atas didominasi oleh perakaran tersier dengan sedikit akar sekunder. Sedangkan secara vertikal bervariasi antara perakaran primer, sekunder dan tersier.

\section{HASIL DAN PEMBAHASAN}

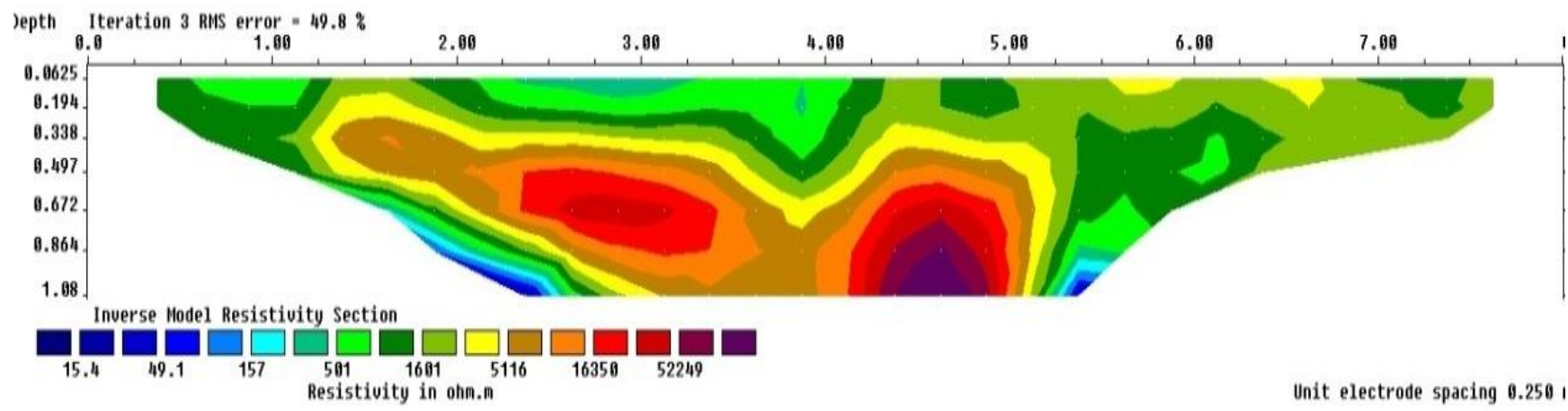

Gambar 1. Penampang Resistivitas Bluto Lintasan 1 
Tabel 1. Hasil interpretasi Bluto lintasan 1 dan 2 dengan Konfigurasi Wenner

\begin{tabular}{ccccc}
\hline Warna Kontur & $\begin{array}{c}\text { Nilai Resistivitas }(\Omega \mathrm{m}) \\
\text { Bluto L1 }\end{array}$ & Nilai Resistivitas $(\Omega \mathrm{m})$ Bluto L2 & \multirow{2}{*}{ Kriteria } & Perakaran \\
\hline & $15,4-157$ & $203-692$ & kecil & tersier \\
\hline
\end{tabular}

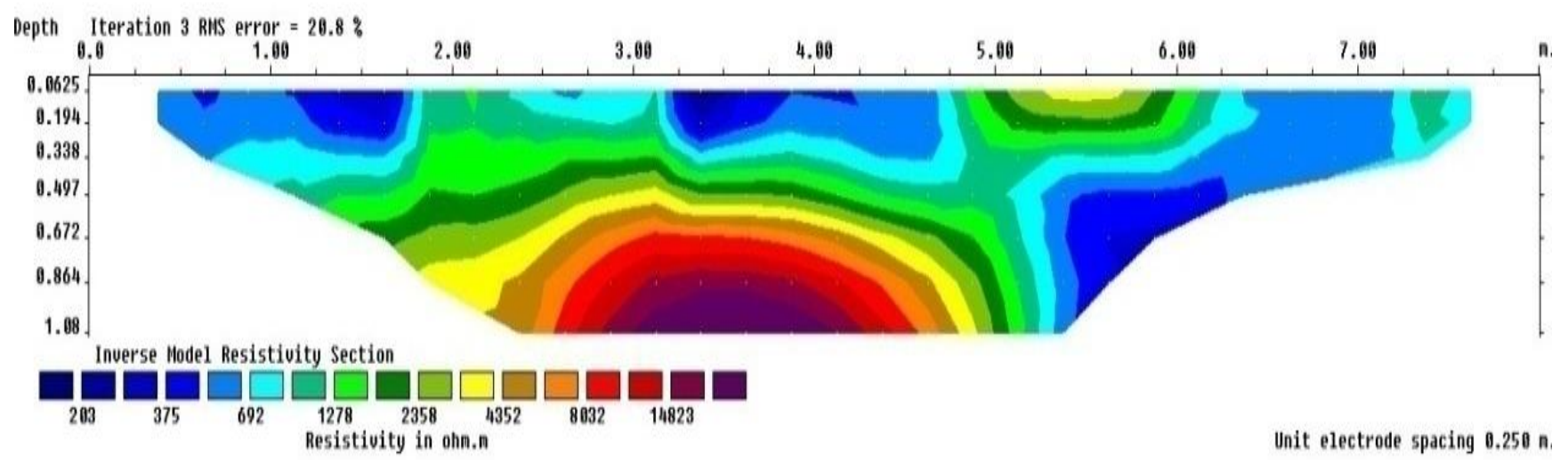

Gambar 2. Penampang Resistivitas Bluto Lintasan 2

\section{b. Lokasi Guluk-guluk lintasan 1 dan 2}

Pengukuran pada lokasi Guluk-guluk lintasan pertama, bila ditinjau dari sebaran resistivitas secara horisontal yaitu berjarak $0,25 \mathrm{~m}$ sampai dengan 7,75 m terlihat adanya nilai resistivitas rendah sekitar 69,6-145 $\Omega \mathrm{m}$ (biru tua hingga biru muda) dari permukaan tanah sampai kedalaman 0,497 $\mathrm{m}$ dari permukaan tanah pada lintasan 0,57,5m. Nilai resistivitas sedang 208-399 $\Omega \mathrm{m}$ (warna hijau muda hingga hijau tua) terdapat pada kedalaman $0,672 \mathrm{~m}$ pada lintasan $7,5 \mathrm{~m}$, sedangkan nilai resistivitas tinggi berkisar 432-623 $\Omega \mathrm{m}$ (warna kuning hingga oranye) dari permukaan tanah sampai kedalaman $0,194 \mathrm{~m}$ pada lintasan 7,5 m. Secara vertikal nilai resistivitas bervariasi antara kecil, sedang dan tinggi pada kedalaman 0,0625-1,00m (Gambar 3). Pada lokasi Guluk-guluk lintasan 1 secara horisontal lapisan yang paling atas didominasi oleh perakaran tersier dengan sedikit akar sekunder dan primer. Sedangkan secara vertikal bervariasi antara perakaran primer, sekunder dan tersier.

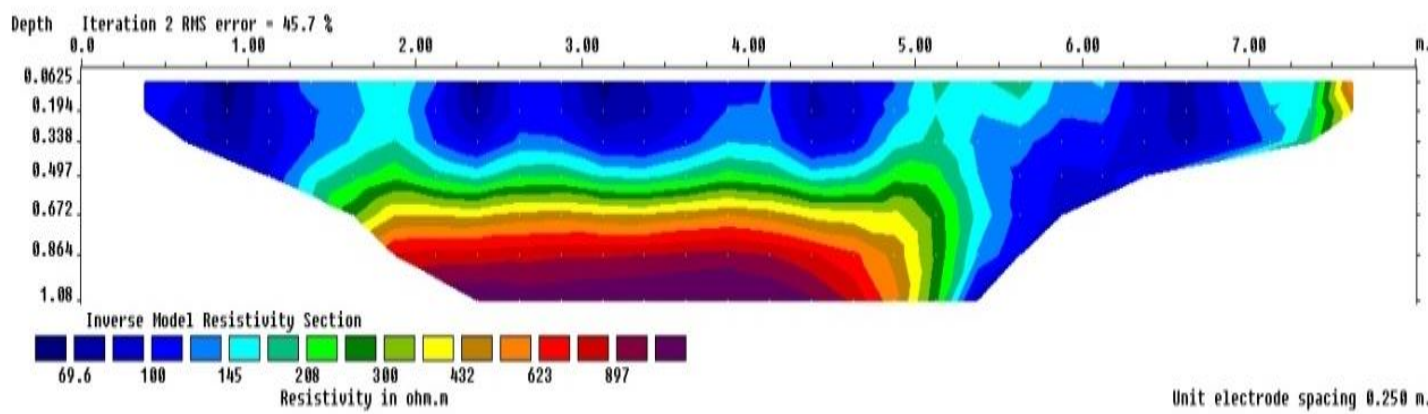

Gambar 3. Penampang Resistivitas di Guluk-guluk Lintasan 1

Tabel 2. Hasil Interpretasi Guluk-guluk Lintasan 1 dan 2 Konfigurasi Wenner

\begin{tabular}{cccccc}
\hline Warna Kontur & $\begin{array}{c}\text { Nilai Resistivitas }(\Omega \mathrm{m}) \\
\text { Guluk-guluk L1 }\end{array}$ & $\begin{array}{c}\text { Nilai Resistivitas }(\Omega \mathrm{m}) \\
\text { Guluk-guluk L2 }\end{array}$ & Kriteria & perakaran \\
\hline $69,6-145$ & $63,1-145$ & kecil & tersier \\
sedang & sekunder & tinggi & primer \\
\hline
\end{tabular}




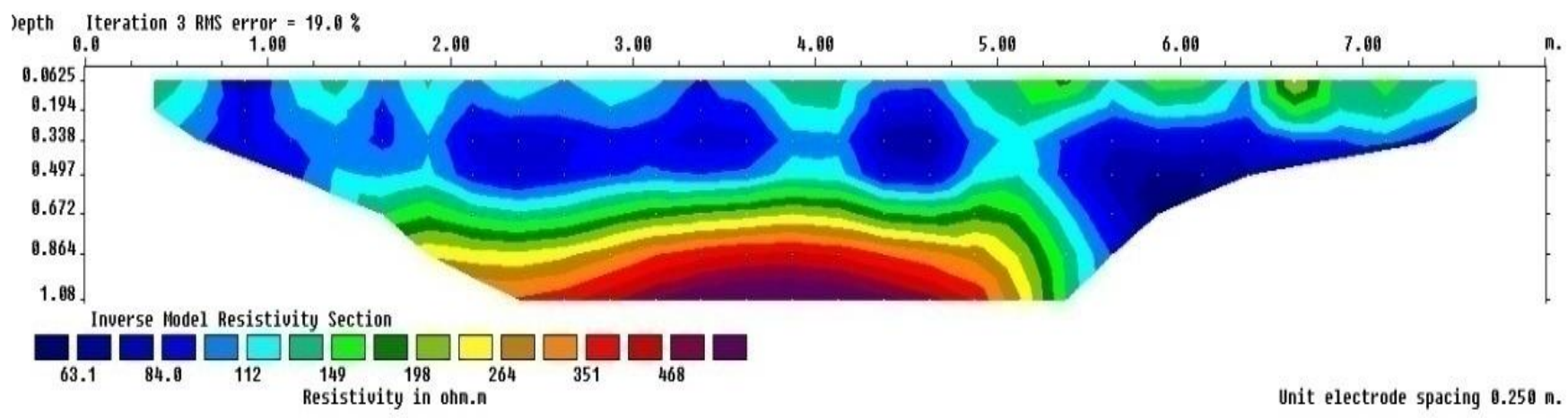

Gambar 4. Penampang Resistivitas di Guluk-guluk Lintasan 2

Pengukuran pada lokasi Guluk-guluk lintasan kedua, bila ditinjau dari sebaran resistivitas secara horisontal yaitu berjarak 0,25 m sampai dengan 7,75 $\mathrm{m}$ terlihat adanya nilai resistivitas rendah sekitar 63,1-112 $\Omega \mathrm{m}$ (biru tua hingga biru muda) dari permukaan tanah sampai kedalaman 0,672 m dari permukaan tanah pada lintasan 0,5-3,75m, 4,25-4,75m. Nilai resistivitas sedang 149-198 $\Omega$ m (warna hijau muda hingga hijau tua) terdapat pada kedalaman $0,338 \mathrm{~m}$ pada lintasan $0,5-3,75 \mathrm{~m}, 4,25-7,5 \mathrm{~m}$. Secara vertikal nilai resistivitas bervariasi antara kecil, sedang dan tinggi pada kedalaman 0,0625-1,00m (Gambar 4). Pada lokasi Gulukguluk lintasan 2 secara horisontal lapisan yang paling atas didominasi oleh perakaran tersier dengan sedikit akar sekunder. Sedangkan secara vertikal bervariasi antara perakaran primer, sekunder dan tersier.

Hasil pengukuran (Tabel 2) setiap lintasan pada lokasi tanaman kelor di Bluto dan Guluk-guluk secara horisontal mempunyai nilai resistivitas rendah yang berada hanya pada bagian atas permukaan tanah sampai kedalaman kurang dari 0,672 $\mathrm{m}$ dengan nilai resistivitas antara 0-300 $\Omega \mathrm{m}$ dimana air tanah berada. Berdasarkan hasil resistivitas, secara horisontal keberadaan nilai resistivitas rendah hanya berada pada bagian atas permukaan tanah sampai kedalaman $60 \mathrm{~cm}$, menunjukkan bahwa kondisi kelembaban tanah lebih dominan dipermukaan tanah dan secara vertikal nilai resistivitasnya bervariasi untuk resistivitas kecil, sedang dan besar. Tanaman kelor yang ditanam pada lokasi tanam di Bluto, di mana tanaman kelor ditanam pada tegalan, pada setiap kriteria (kecil, sedang dan besar) mempunyai nilai resistivitas lebih besar dibandingkan dengan tanaman kelor di Guluk-guluk yang di tanam pada pematang. Hal ini disebabkan karena kadar air aktual di Bluto lebih rendah atau lebih kering yang jika diinjeksi arus maka akan sulit untuk menghantarkan arus listrik sehingga nilai resistivitasnya lebih tinggi dibandingkan dengan di Gulukguluk.

Menurut Nazari et al. (2015), kondisi tanah yang lembab di permukaan tanah mendorong pergerakan akarakar tanaman terutama perakaran aktif jenis akar tersier dan kuarter. Hal ini disebabkan karena akar tersier dan kuarter sangat aktif dalam menyerap unsur hara dan air dalam tanah. Agar unsur hara dan air tersebut mudah diserap maka terlebih dahulu harus diurai dalam bentuk ion. Ion-ion tersebut bermuatan listrik sehingga bila diinjeksikan arus padanya, maka dengan mudah akan menghantarkan listrik sehingga mengakibatkan nilai resistivitasnya menjadi kecil. Menurut Islami dan Utomo (1995), kelembaban tanah mempengaruhi pertumbuhan akar tidak hanya secara langsung tetapi juga tidak langsung karena kelembaban tanah akan mempengaruhi aerasi tanah. Pertumbuhan akar tanaman tumbuh ke arah air tanah. Selain itu akar membutuhkan hara mineral yang cukup untuk pertumbuhan dan perkembangannya. Pada keadaan tanah yang subur dengan banyak kandungan hara maka akar akan cenderung membentuk perakaran yang banyak. Sistem perakaran yang matang menempati volume tanah yang relatif tetap pada kedalaman tertentu, hingga pengambilan air hanya tergantung pada volume, kandungan air tanah, sifat hidrauliknya serta kerapatan perakaran (Susanto dan Purnomo, 1998).

\section{KESIMPULAN}

Sebaran akar kelor di Bluto dan Guluk-guluk bervariasi terdiri dari akar tersier, sekunder dan primer dapat dilihat hasil resistivitas secara horisontal dan vertikal. Nilai resistivitas lokasi tanam kelor di Bluto lebih tinggi dibandingkan dengan di Guluk-guluk.

\section{DAFTAR PUSTAKA}

Al Hagrey, S.A. dan J. Michaelsen. (1999). Resistivity and percolation study of prefential flow in Vadose Zone at Bokhorst, Germany. J. Geophysics. 64(3), 746 753.

Arifin, Z dan E.T.S. Putra. (2015). Panduan alat geolistrik. Laboratorum Ilmu Tanaman. Jurusan Agronomi. Fakultas Pertanian. Universitas Gadjah Mada. Yogyakarta.

Arifin, Z, M. Sarwendah, E.T.S. Putra. (2015). Metode geolistrik dalam penentuan sebaran akar kelapa sawit. Prosiding Seminar Nasional. Fakultas Pertanian. Universitas Gadjah Mada

Islami, T dan W. H. Utomo, (1995). Hubungan tanah, air dan tanaman. IKIP Semarang Press. 297p.

Makkar dan Becker, (1996). Nutrient and antiquality factors in different morphological parts of the Moringa oleifera tree. J.Agric. Sci. Cambridge. 128, 311-322. 
Martoyo, K. (2001). Perananan Beberapa Sifat Fisik Tanah Ultisol Pada Penyebaran Akar Tanaman Kelapa Sawit (Elaeis guineensis Jacq.) Warta Pusat Penelitian Kelapa Sawit 9 (3), 103-110.

Miftahuddina, Joko Sampurnoa, Andi Ihwana. (2016). Pendugaan Sebaran Akar Kelapa Sawit Pada Lahan Gambut Dengan Menggunakan Metode Geolistrik Resitivitas. Prisma Fisika, 4(3), 114 - 120.

Nazari, Y. A dan Sota, I. (2012). Deteksi sebaran akar kelapa sawit dengan metode geolistrik resistivitas.
Agroscientiae. 19(2), 112-115.

Nazari, Y. A., Fakhrurrazie, N. Aidawati, dan Gunawan. (2015). Deteksi perakaran kelapa sawit pada lubang biopori modifikasi dengan metode geolistrik resistivitas. Ziraa'ah. 40(1), 31-39.

Risza, S. (1994). Upaya Meningkatkan Produktivitas Kelapa Sawit. Kanisius. Yogyakarta

Susanto, R.,H dan R. H. Purnomo. (1998). Pengantar Fisika Tanah. Mitra Gama Widya. Yogyakarta. 